\title{
Pembuatan Mesin Pencacah Sampah Organik Untuk Swadaya Pupuk di Desa Tancep Kecamatan Ngawen Kabupaten Gunungkidul
}

\author{
Ignatius Aris Hendaryanto \\ Departemen Teknik Mesin Sekolah Vokasi Universitas Gadjah Mada \\ Email: aris.hendaryanto@ugm.ac.id
}

\begin{abstract}
Abstrak
Untuk meningkatkan hasil pertanian dan perkebunan, petani sangat membutuhkan pupuk. Saat ini permasalahan yang dihadapi para petani di Desa Tancep Kecamatan Ngawen Kabupaten Gunungkidul adalah kelangkaan dan tingginya harga pupuk. Di sisi lain, daerah tersebut memiliki potensi yang besar, berupa ketersediaan bahan-bahan organik dan kotoran hewan ternak yang dapat dimanfaatkan menjadi pupuk. Dalam kegiatan pengabdian kepada masyarakat ini diberikan pengetahuan dan teknologi sederhana untuk mengolah sampah dan bahan-bahan organik lain menjadi pupuk kompos. Proses pembuatan pupuk kompos memerlukan proses mencacah sampah atau bahan-bahan organik, seperti daun dan ranting basah, sehingga menjadi potongan-potongan berukuran kecil. Untuk itu dalam kegiatan ini perlu dilakukan pembuatan mesin pencacah sampah atau bahan-bahan organik. Mesin pencacah sampah organik dibuat dengan konstruksi pisau putar (rotary blade) satu poros yang terdiri dari 12 pisau. Konstruksi mesin dibuat portabel dengan penggerak berupa mesin bensin, sehingga mesin mudah dipindah dan dioperasikan di dalam atau di luar ruangan. Melalui kegiatan pengabdian kepada masyarakat di Desa Tancep Kecamatan Ngawen Kabupaten Gunungkidul telah terbentuk bank sampah yang dikelola oleh kelompok Karang Taruna. Selain mengumpulkan dan menjual kembali sampah anorganik, kegiatan yang dikembangkan adalah pengolahan sampah organik menjadi pupuk kompos. Melalui pengetahuan dan peralatan yang dimiliki, diharapkan pupuk kompos yang diproduksi dapat membantu memenuhi kebutuhan pupuk bagi petani setempat menuju swadaya pupuk.
\end{abstract}

Kata kunci: sampah organik, mesin pencacah sampah, pupuk kompos

\begin{abstract}
To improve agricultural and plantation yields, farmers need fertilizer. Currently the problems faced by farmers in Tancep Village Ngawen District Gunungkidul Regency is the scarcity and high price of fertilizer. On the other hand, the area has great potential, in the form of availability of organic materials and animal manure that can be utilized as fertilizer. In this community service the knowledge and simple technology to process waste and other organic materials into compost were given. The process of making compost requires the process of chopping garbage or organic materials, such as wet leaves and twigs, so that the pieces are small. For that in this activity needs to be done making garbage chopper machine or organic materials. An organic waste counter machine is made with a rotary blade construction consisting of 12 blades. The construction of a machine is made portable with a propulsion in the form of a gasoline engine, so the machine is easily moved and operated indoors or outdoors. Through community service activities in Tancep Village, Ngawen Subdistrict, Gunungkidul Regency has formed a garbage bank managed by Karang Taruna group. In addition to collecting and reselling of inorganic waste, the activity developed is processing organic waste into compost. Through the knowledge and equipment
\end{abstract}


owned, it is expected that the compost fertilizer produced can help meet the needs offertilizer for local farmers to self-help fertilizer.

Keywords: organic waste, garbage chopper machine, compost fertilizer

\section{PENDAHULUAN}

Desa Tancep merupakan salah satu desa yang berada di wilayah Kecamatan Ngawen Kabupaten Gunungkidul Propinsi
Daerah Istimewa Yogyakarta, terletak $25 \mathrm{~km}$ di sebelah timur laut kota Wonosari. Luas wilayah kecamatan Ngawen 4.569,37 ha yang terbagi menjadi 6 desa, 66 pedukuhan, 66 RW dan 256 RT.

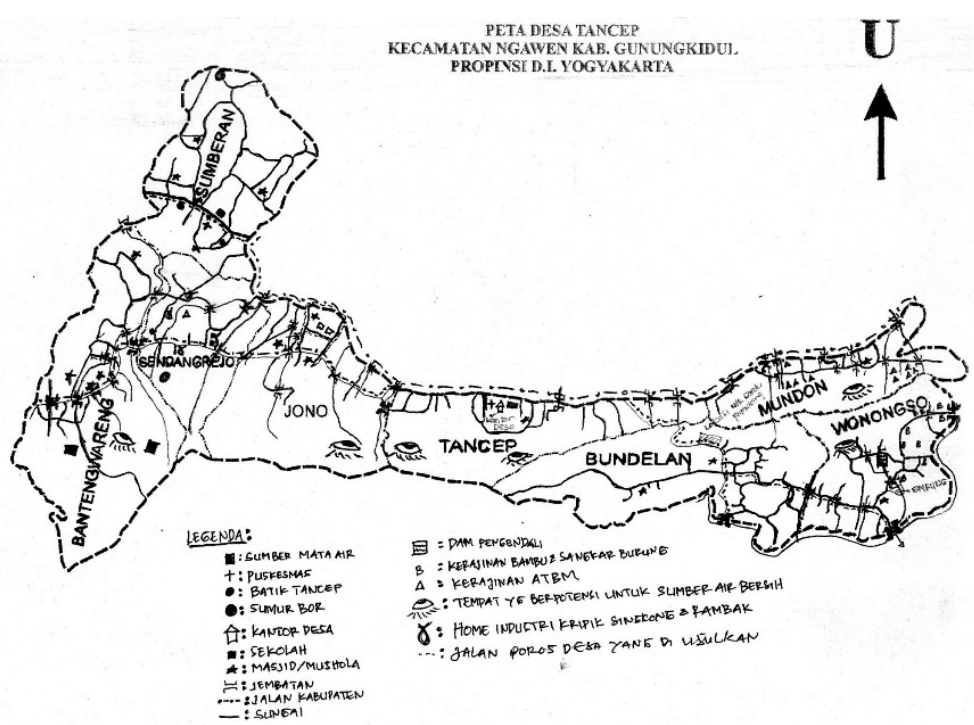

Gambar 1. Peta Wilayah Desa Tancep, Kecamatan Ngawen, Kabupaten Gunungkidul

Kecamatan Ngawen mempunyai luas lahan 4.529,9 ha terdiri dari lahan sawah/ladang seluas 1101,1 ha $(24,08 \%)$. Secara geografis Kecamatan Ngawen memiliki ketinggian sekitar 600 mdpl dengan suhu berkisar antara 25 sampai 32 derajat Celcius. Curah hujan di Kecamatan Ngawen pada tahun 2007 berkisar antara 538 sampai 1256 $\mathrm{mm} /$ tahun dengan jumlah hari hujan terbanyak 86 hari. Musim hujan dimulai bulan Nopember dan berakhir pada bulan Maret-April dengan puncak hujan bulan Desember-Pebruari. Dilihat dari bentuk wilayahnya sebagian besar merupakan perbukitan dengan kemiringan antara $0-40$ $\%$, dari luas keseluruhan yang berbentuk dataran hanya mencapai $15 \%$. Dengan kondisi geografis seperti itu, dari total jumlah penduduk Kecamatan Ngawen sebanyak 36.291 jiwa, mayoritas memiliki mata pencaharian di bidang pertanian, yaitu sebanyak 17.156 jiwa $(47,27 \%$ dari total jumlah penduduk).

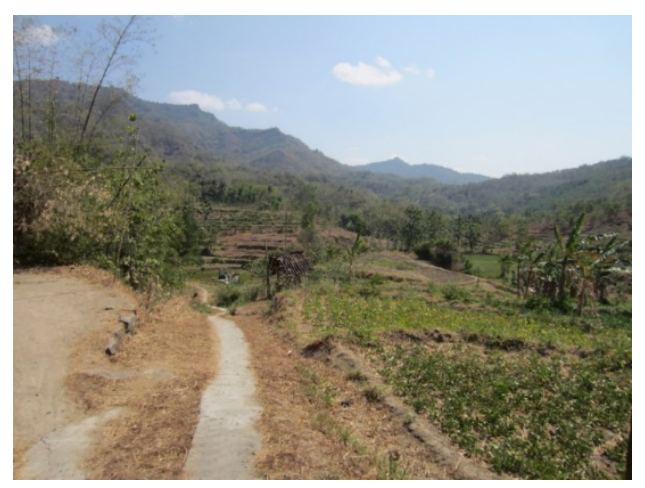

Gambar 2. Kondisi lahan pertanian Desa Tancep Kecamatan Ngawen. 
Saat ini petani di Desa Tancep Kecamatan Ngawen Kabupaten Gunungkidul dihadapkan pada permasalahaan kelangkaan pupuk dan tingginya harga pupuk. Di satu sisi, untuk meningkatkan hasil pertanian, mereka sangat membutuhkan pupuk. Mengingat besarnya potensi yang dimiliki oleh daerah tersebut, berupa ketersediaan bahan-bahan organik, kotoran hewan ternak, serta sumber daya manusianya, maka teknologi pembuatan pupuk dengan bahan dasar lokal dapat ditingkatkan baik dari segi kualitas maupun kuantitas.

Keterbatasan pengetahuan dan teknologi menyebabkan potensi sumber daya yang ada tidak dapat dimanfaatkan dengan baik. Misalnya para petani dan peternak (sapi atau kambing) lebih suka menjual kotoran hewan ternak dan hasil penjualannya digunakan untuk membeli pupuk buatan, dengan perbandingan harga yang sangat jauh berbeda. Sebagai contoh harga pupuk kotoran hewan ternak (sapi atau kambing) sebanyak satu bak truk sama dengan harga pupuk buatan 5 atau $10 \mathrm{~kg}$ di pasaran (tergantung merek dagangnya). Keadaan ini sangat ironis dan sangat tidak seimbang.

Berdasarkan permasalahan di atas, dalam kegiatan pengabdian masyarakat ini, tim akan memberikan pengetahuan dan teknologi sederhana untuk mengolah sampah dan bahan-bahan organik lain menjadi pupuk kompos. Dalam proses pembuatan pupuk kompos ini diperlukan tahapan proses mencacah sampah atau bahan-bahan organik sehingga berukuran kecil-kecil. Untuk itu dalam kegiatan ini perlu dilakukan pembuatan mesin pencacah sampah atau bahan-bahan organik.

Berdasarkan latar belakang permasalahan di atas, maka dapat dirumuskan permasalahan pada beberapa hal sebagai berikut:

1. Petani menghadapi permasalahan kelangkaan pupuk dan tingginya harga pupuk.

2. Desa Tancep memiliki potensi yang besar berupa ketersediaan bahanbahan organik, kotoran hewan ternak, serta sumber daya manusianya, tetapi keterbatasan pengetahuan dan teknologi menyebabkan potensi sumber daya yang ada tidak dapat dimanfaatkan dengan baik.

3. Perlunya diberikan pengetahuan dan teknologi sederhana untuk mengolah sampah dan bahan-bahan organik lain menjadi pupuk kompos, serta sarana prasarana berupa alat pencacah sampah organic.

\section{Tujuan Kegiatan}

Tujuan Kegiatan Pengabdian Kepada Masyarakat ini antara lain :

1. Meningkatkan pengelolaan sampah organik agar tidak mengganggu lingkungan warga Desa Tancep, Kecamatan Ngawen, Kabupaten Gunungkidul.

2. Meningkatkan produksi pupuk kompos dari bahan lokal sehingga dapat mengatasi kebutuhan pupuk sehingga dapat tercapai swadaya pupuk bagi petani di Desa Tancep, Kecamatan Ngawen, Kabupaten Gunungkidul.

3. Meningkatkan kesejahteraan warga dengan mengurangi pengeluaran untuk pembelian pupuk buatan yang harganya terus naik.

\section{Manfaat Kegiatan}

Manfaat kegiatan Pengabdian Kepada Masyarakat ini antara lain:

1. Perekonomian berkembang karena warga mendapatkan hasil pertanian yang meningkat karena telah tercukupinya kebutuhan akan pupuk.

2. Peningkatan pendapatan dan kesejahteraan warga sehingga jumlah rakyat miskin berkurang.

3. Peningkatan pengetahuan petani warga desa sehingga dapat mempunyai ketahanan pangan yang tinggi.

\section{Pengelolaan Sampah Organik}

Dalam istilah lingkungan, sampah diartikan sebagai: "bahan yang terbuang atau dibuang dari hasil kegiatan manusia maupun proses alam yang belum memiliki nilai ekonomis." (Istilah Lingkungan untuk 
Manajeman, Ecolink, 1996). Namun, tidak semua sampah tidak berguna. Beberapa jenis sampah masih dapat diolah sehingga memiliki nilai ekonomi atau kegunaan lain bagi manusia. Untuk itu, diperlukan pemahaman tentang sampah dan bagaimana mengelolanya agar berguna. Salah satu bentuk pengelolaan sampah organik adalah diolah menjadi pupuk kompos. Pembuatan pupuk kompos dapat mengurangi masalah sampah sekaligus menciptakan nilai ekonomi dari sampah.

Bahan baku pembuatan pupuk kompos adalah berupa bahan-bahan organik atau dari sampah organik. Sampah organik adalah sampah yang bisa mengalami pelapukan (dekomposisi) dan terurai menjadi bahan yang lebih kecil dan tidak berbau, atau sering disebut dengan kompos. Sampah organik bisa berasal dari makhluk hidup, baik manusia, hewan, maupun tumbuhan. Sampah organik sendiri dibagi menjadi dua, yaitu sampah organik basah, sampah yang mempunyai kandungan air yang cukup tinggi, dan sampah organik kering bahan organik lain yang kandungan airnya kecil. Contoh sampah organik basah misalnya kulit buah, sisa sayuran, sedangkan contoh sampah organik kering di antaranya kertas, kayu atau ranting pohon, dan dedaunan kering.

Kompos adalah hasil penguraian parsial/tidak lengkap dari campuran bahanbahan organik yang dapat dipercepat secara artifisial oleh populasi berbagai macam mikroba dalam kondisi lingkungan yang hangat, lembap, dan aerobik atau anaerobik (Modifikasi dari J.H. Crawford, 2003). Sedangkan pengomposan adalah proses dimana bahan organik mengalami penguraian secara biologis, khususnya oleh mikroba-mikroba yang memanfaatkan bahan organik sebagai sumber energi. Membuat kompos adalah mengatur dan mengontrol proses alami tersebut agar kompos dapat terbentuk lebih cepat. Proses ini meliputi pencampuran bahan yang seimbang, pemberian air yang cukup, pengaturan aerasi, dan penambahan aktivator pengomposan. Dilihat dari proses pembuatannya terdapat dua macam cara membuat kompos, yaitu melalui proses aerob (dengan udara) dan anaerob (tanpa udara). Kedua metode ini menghasilkan kompos yang sama baiknya hanya saja bentuk fisiknya agak sedikit berbeda.

\section{Mesin Pencacah Sampah Organik}

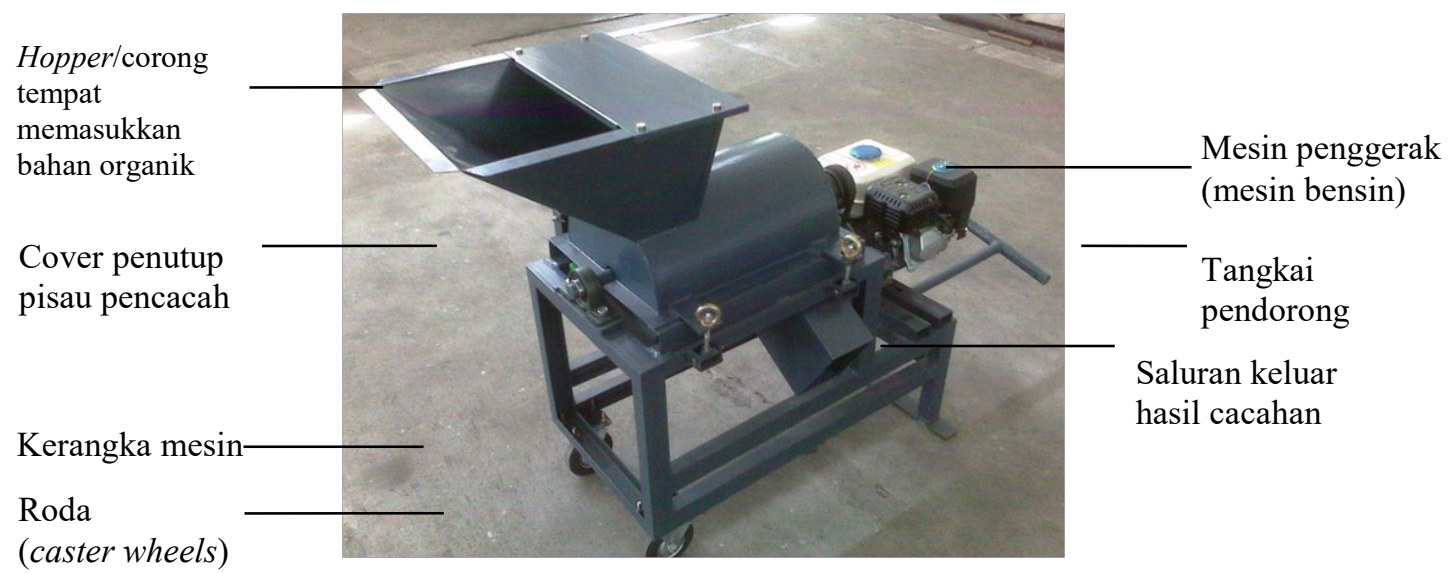

Gambar 3. Mesin pencacah sampah/bahan organik.

Bahan baku pupuk kompos yang berasal dari sampah organik atau bahanbahan organik lain harus dicacah menjadi potongan-potongan kecil sebelum diolah.
Proses mencacah sampah/bahan organik seperti daun-daun basah, ranting-ranting kecil, sampah rumah tangga, dan lain-lain dapat dilakukan secara manual, tetapi 
untuk mempercepat dan mempermudah proses pencacahan dibutuhkan mesin

pencacah, seperti ditunjukkan pada Gambar

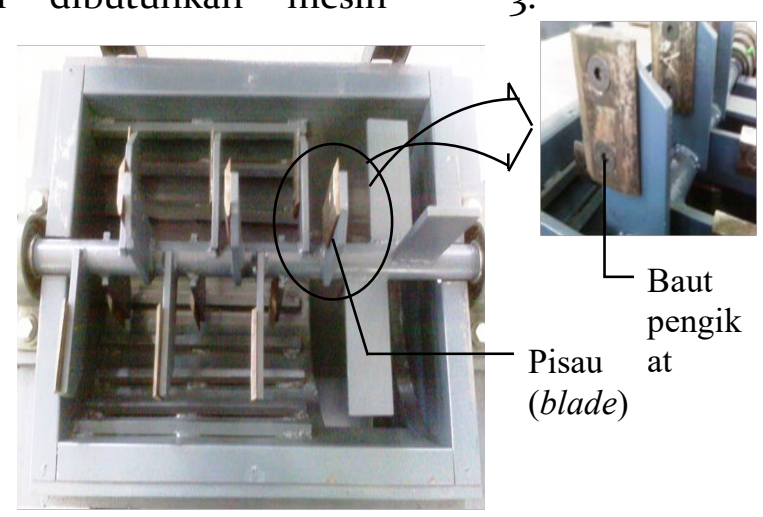

Gambar 4. Poros pisau putar.

Mesin ini dibuat portable dan dapat dipindah-pindahkan dengan mudah karena kerangka mesin dilengkapi dua buah roda dan tangkai pendorong. Dengan penggerak utama berupa mesin berbahan bakar bensin berkapasitas 5hp, memungkinkan mesin pencacah sampah organik ini dapat dioperasikan di dalam atau di luar ruangan. Mekanisme pencacah menggunakan pisau putar (rotary blade) satu poros, yang terdiri dari 12 pisau seperti ditunjukkan pada gambar 4. Pisau diikat dengan baut, sehingga dapat dilepas untuk diasah jika tumpul, dan kemudian dipasang kembali dengan mudah.

Bahan-bahan organik yang dimasukkan melalui hopper/corong akan dirajang/dicacah oleh pisau-pisau pencacah yang diputar oleh mesin bensin. Hasil cacahan berupa potongan-potongan berukuran kecil akan keluar melalui saluran keluar dan ditampung pada wadah yang ditempatkan di depan saluran keluar.

\section{KERANGKA PEMECAHAN MASALAH}

Sejalan dengan program yang dicanangkan oleh pemerintah setempat dalam rangka penanganan masalah sampah, maka dalam rangkaian kegiatan Pengabdian Kepada Masyarakat ini dilakukan pembinaan dan penyuluhan serta pelatihan kepada warga masyarakat, khususnya kelompok pemuda Karang Taruna. Bentuk kegiatan yang dilakukan adalah dengan membentuk organisasi bank sampah.
Dengan membentuk organisasi bank sampah, maka masyarakat akan mengerti, memahami dan menerapkan pengumpulan sampah (bank sampah) serta memilahmilah sampah. Sampah berbahan anorganik, seperti plastik, kertas, dan lainlain kemudian bisa dijual ke pengepul untuk didaur ulang, sehingga dapat menambah pendapatan. Sementara sampah berbahan organik kemudian dapat diolah menjadi pupuk kompos, sehingga dapat mengurangi pengeluaran dalam pengadaan pupuk. Dengan demikian bank sampah akan memberikan manfaat ganda yaitu pendapatan dari hasil penjualan sampah anorganik dan pengurangan pengeluaran belanja pupuk. Bila jumlah pupuk kompos yang bisa diproduksi sudah memenuhi kebutuhan petani setempat, maka sisanya dapat dijual ke tempat lain yang membutuhkan pupuk organik, sehingga di kemudian hari akan menambah pendapatan petani juga.

\section{METODE}

Organisasi bank sampah yang diberi nama bank sampah "Tancep Bersih" telah dirintis dan dikelola oleh kelompok pemuda Karang Taruna Dusun Sendang Rejo Desa Tancep. Organisasi ini awalnya direncanakan meliputi seluruh desa, namun karena terlalu luasnya wilayah desa sehingga muncul kendala pengelolaannya maka kegiatan ini diperkecil ruang lingkupnya, diawali dengan pilot project dari Dusun Sendang Rejo Desa Tancep, dengan 
harapan stimulasi ini akan ditiru untuk seluruh dusun di Desa Tancep.

Melalui penyuluhan dan pelatihan yang telah diberikan tentang metode pembuatan pupuk kompos dan pemberian bantuan sarana prasarana berupa mesin pencacah sampah/bahan organik serta peralatan pembuat pupuk kompos, diharapkan kegiatan pembuatan pupuk kompos ini akan menjadi agenda kegiatan bagi kelompok pemuda Karang Taruna Dusun Sendang Rejo Desa Tancep. Selanjutnya produk pupuk kompos yang dihasilkan ini akan dimanfaatkan oleh para petani setempat sehingga diharapkan ke depannya Desa Tancep bisa menjadi desa yang bisa berswadaya pupuk.

\section{Tahapan Kegiatan}

Kegiatan ini diawali dari pertemuan antara tim kegiatan Pengabdian Kepada Masyarakat dengan Kepala Desa Tancep dan staff serta perwakilan warga masyarakat dan pemuda Karang Taruna, untuk menggali permasalahan yang ada di Desa Tancep.

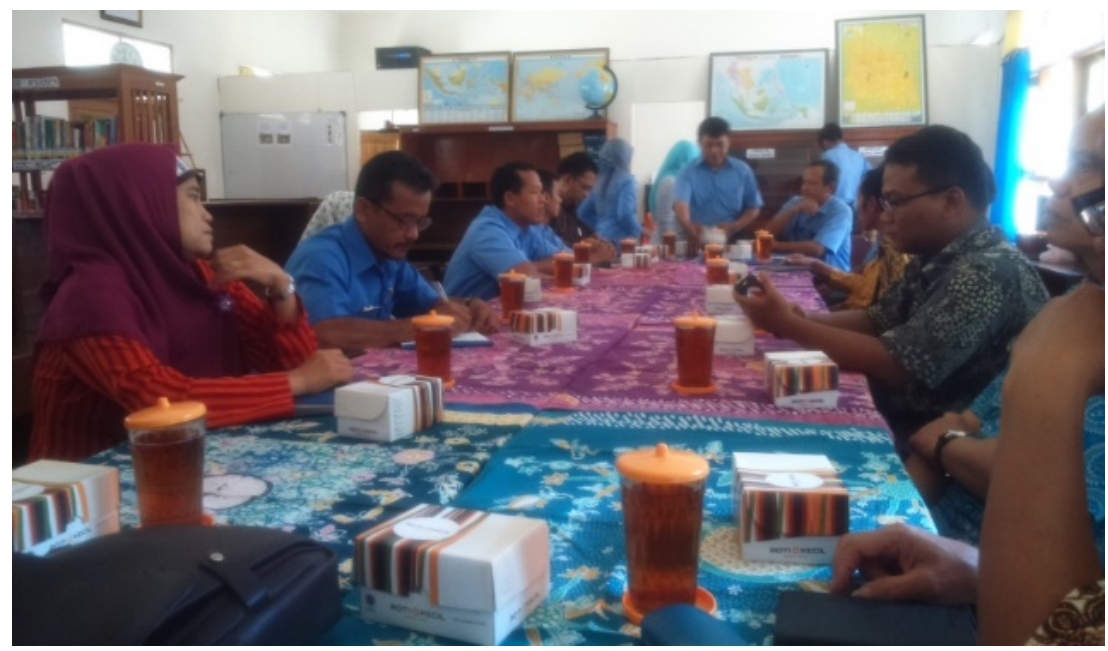

Gambar 5. Pertemuan antara tim kegiatan Pengabdian Kepada Masyarakat dengan pemerintah Desa Tancep beserta staf serta perwakilan warga masyarakat

$\begin{aligned} & \text { Dari hasil pertemuan } \begin{array}{r}\text { tersebut } \\ \text { dirumuskan }\end{array} \\ & \text { kemudian } \\ & \text { permasalahan untuk diambil sebagai topik }\end{aligned}$
kegiatan Pengabdian Kepada Masyarakat,
yang mencakup kebutuhan dari setiap
perwakilan warga masyarakat.
Permasalahan utama meliputi kelangkaan
pupuk dan mahalnya harga pupuk buatan
pabrik yang dikeluhkan oleh petani serta
keinginan kelompok Karang Taruna untuk
belajar mengelola bank sampah.
Tahapan kegiatan yang dilakukan
selanjutnya adalah sebagai berikut:
a. Sosialisasi tentang pentingnya
pengelolaan sampah dan tentang

rencana pendirian bank sampah Desa Tancep serta sosialisasi tentang pemanfaatan sampah organik untuk diolah menjadi pupuk kompos kepada kelompok-kelompok Karang Taruna Desa Tancep. Dalam acara ini juga telah dibentuk pengurus bank sampah.

b. Pertemuan dengan pengurus bank sampah tentang cara pengelolaan bank sampah.

c. ejalan dengan kegiatan penyuluhan dan sosialisasi bank sampah, juga dilakukan pembuatan mesin pencacah sampah organik. 


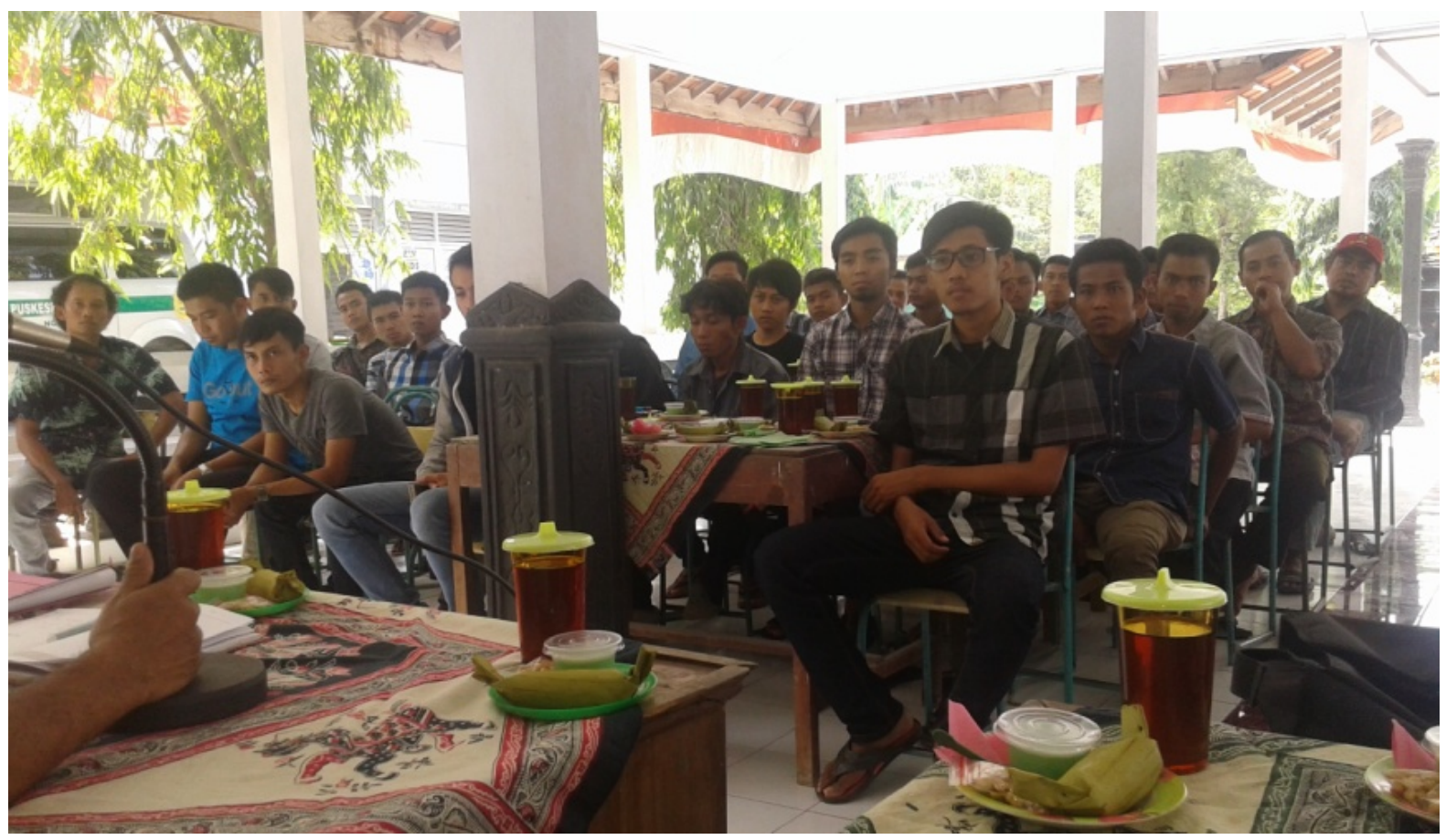

Gambar 6. Sosialisasi bank sampah dan pentingnya pengelolaan sampah.

d. Sosialisasi dan penyuluhan/ pelatihan metode pembuatan pupuk kompos kepada pemuda Karang Taruna Dusun Sendang Rejo Desa Tancep. Dalam acara ini juga dilakukan serah terima

peralatan pembuat pupuk Kompos dan mesin pencacah sampah organik.

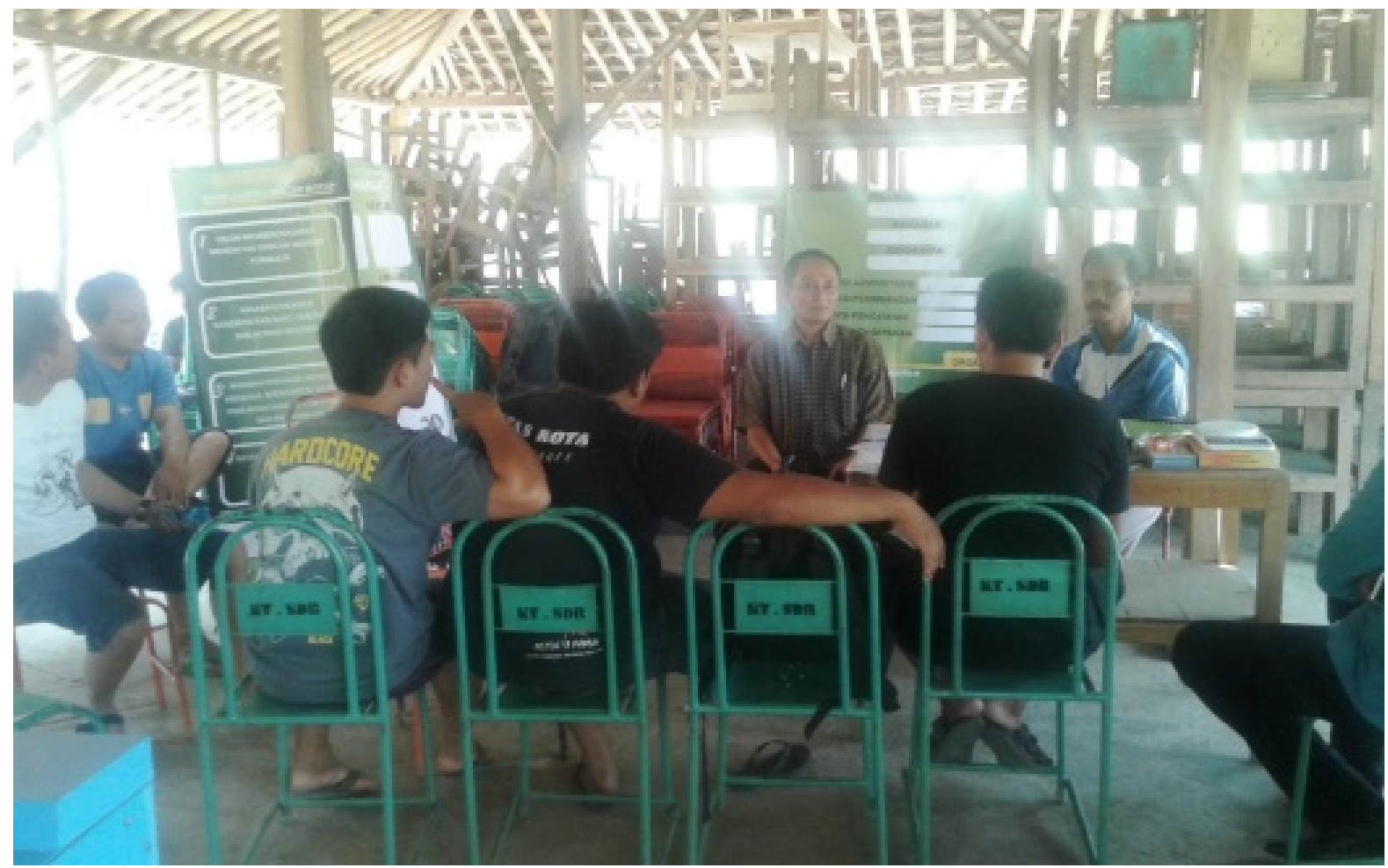

Gambar 8. Penyuluhan tentang metode pembuatan pupuk kompos. 


\section{HASIL DAN PEMBAHASAN}

Hasil dari Kegiatan Pengabdian Kepada Masyarakat Departemen Teknik Mesin, Sekolah Vokasi, UGM Tahun Anggaran 2015 ini berupa pembuatan mesin pencacah sampah/bahan organik untuk bahan baku pembuatan pupuk kompos. Mesin pencacah sampah/bahan organik ini untuk mendukung kegiatan Karang Taruna Dusun Sendang Rejo Desa Tancep Kecamatan Ngawen Kabupaten Gunungkidul dalam rangkaian kegiatan pengelolaan sampah di organisasi bank sampah "Tancep Bersih". Dalam kegiatan ini, dilakukan pengumpulan sampah dari warga masyarakat di bank sampah, kemudian dilakukan pemilahan sampah anorganik dan sampah organik. Sampah anorganik dijual ke pengepul untuk didaur ulang dan sampah organik diolah menjadi pupuk kompos.

Pemerintah Desa Tancep sangat antusias dan sangat mendukung kegiatan ini, terlihat dari ikut sertanya Bapak Kepala Desa (Bapak Tri Hartono) dalam setiap rangkaian acara pertemuan. Hal ini dikarenakan kegiatan ini dinilai sejalan dengan program pemerintah desa mengenai pengelolaan sampah. Selain itu program ini dinilai dapat memberikan kegiatan positif bagi pemuda Karang Taruna Desa Tancep yang dapat memberikan manfaat secara ekonomi dari penjualan sampah anorganik serta membantu petani dalam upaya menuju swadaya pupuk.

\section{SIMPULAN}

Pembuatan mesin pencacah sampah organik dalam rangka mendukung kegiatan pengelolaan sampah khususnya pengolahan sampah organik menjadi pupuk kompos telah terlaksana dengan baik sesuai rencana atas dukungan dan partisipasi masyarakat khususnya kelompok Karang Taruna Desa Tancep. Kegiatan Pengabdian Kepada Masyarakat ini dapat dinilai sudah tepat sasaran hingga kepada target masyarakat penerima, sehingga selain dapat memberikan kegiatan positif bagi kelompok Karang Taruna Desa Tancep, juga dapat membantu memenuhi kebutuhan pupuk bagi petani setempat dalam upaya menuju swadaya pupuk.

\section{DAFTAR PUSTAKA}

Ecolink. (1996). “Kamus Istilah Lingkungan untuk Manajemen".

Hita Hamastuti, Elysa Dwi O, S.R Juliastuti, dan Nuniek Hendrianie "Peran Mikroorganisme Azotobacter chroococcum, Pseudomonas fluorescens, dan Aspergillus niger pada Pembuatan Kompos Limbah Sludge Industri Pengolahan Susu”, Jurnal teknik Pomits Vol. 1, No. 1, (2012) 1-5.

Ika Kristina Dewi. (2008). Evaluasi Proses Komposting Dalam Rangka Peningkatan Produksi Kompos, Studi kasus: UPT pengolahan sampah dan limbah kota Probolinggo.

Krisantini, M. Yusuf dan B. Tjia, "Pengaruh Sterillisasi dan Dosis Pupuk Kandang Terhadap Pertumbuhan Umbi Callalily (Zanthedeschiae)", Bul. Agron. 24(1): 21-24 (1996).

http://alamtani.com/cara-membuatkompos.html, "Cara membuat kompos" diakses 13-11-2015. ।

http://www.gunungkidulkab.go.id/home.p hp?mode=content\&id=13 "Profil Kecamatan Ngawen Kabupaten Gunungkidul", diakses 13-11-2015 